\title{
Théologiques
}

\section{Reconnaissance et bienvenue !}

\section{Guy Lapointe}

Volume 8, numéro 1, printemps 2000

La superstition

URI : https://id.erudit.org/iderudit/005017ar

DOI : https://doi.org/10.7202/005017ar

Aller au sommaire du numéro

Éditeur(s)

Faculté de théologie de l'Université de Montréal

ISSN

1188-7109 (imprimé)

1492-1413 (numérique)

Découvrir la revue

Citer ce document

Lapointe, G. (2000). Reconnaissance et bienvenue ! Théologiques, 8(1), 3-3. https://doi.org/10.7202/005017ar d'utilisation que vous pouvez consulter en ligne.

https://apropos.erudit.org/fr/usagers/politique-dutilisation/ 


\section{Reconnaissance et bienvenue!}

La Direction de la revue Théologiques tient à remercier les collègues Denise Couture, trésorière, et Robert David, secrétaire, qui ont œuvré à la Revue depuis 1993. J'aimerais souligner le travail immense et efficace que ces deux collègues ont accompli pendant près de 10 ans, puisqu'ils ont, tous deux, collaboré à la naissance de Théologiques. Au nom des lecteurs et lectrices de la revue et des membres du Comité de rédaction, je leur témoigne toute ma reconnaissance.

Deux nouveaux collègues se joignent à la Direction. Jean-Marc Gauthier assumera la tâche de secrétaire, Alain Gignac, celle de trésorier. À ces deux collègues, je souhaite la bienvenue dans l'équipe.

Guy LAPOINTE, directeur 